\title{
Dampak IFRS 15 Bagi Laporan Keuangan Perusahaan Konstruksi
}

\section{Moch. Yasin Dwi Ervinda1, Muhammad Hadiyan Ridho}

1Politeknik Keuangan Negara STAN, Indonesia

${ }^{2}$ Politeknik Keuangan Negara STAN, Indonesia

\section{Article Info}

Article history:

Received:2020-04-26;

Accepted:2020-0617;

Published:2020-07-15;

Kata Kunci:

Boygues SA ,IFRS 15, Kontrak, Pendapatan

\section{Abstract}

This study aims to analyze the impact of the implementation of IFRS 15 associated with the recognition of contract revenue with customers at the Boygues SA company in France. The research method used in this study is a qualitative method. The steps taken in this study by using content analysis that is collecting data, documenting and analyzing. This study uses the 2017 financial statements before and after implementation of IFRS 15 as a basis for evaluating the impact from those implemetation. The results showed that the application of IFRS 15 did not significantly influence the company's revenue or overall Financial Report.

\section{Abstrak}

Penelitian ini bertujuan untuk menganalisis dampak penerapan IFRS 15 terhadap pengakuan pendapatan kontrak dengan pelanggan di perusahaan Boygues SA di Perancis. Metode penelitian yang digunakan adalah metode kualitatif. Dengan menggunakan laporan keuangan 2017 sebelum dan sesudah implementasi IFRS 15 sebagai dasar untuk mengevaluasi dampak dari implementasi tersebut. Hasil Penelitian menunjukkan bahwa penerapan perusahaan atau keseluruhan Laporan Keuangan.
Cara mengutip:

Ervinda, M. Y. D \& Ridho, M. H. (2020). Dampak IFRS 15 Bagi Laporan Keuangan Perusahaan Konstruksi. Keberlanjutan : Jurnal Manajemen dan Jurnal Akuntansi, 5 (1), 38-50
Email Penulis. ervinda95@gmail.com,mhadyanridhooo@gmail.com 


\section{PENDAHULUAN}

Pengakuan pendapatan yang berlaku secara internasional diatur dalam International Accounting Standard (IAS) nomor 18, sedangkan khusus pengakuan pendapatan atas kontrak konstruksi jangka panjang atau multi years diatur dalam IAS nomor 11. Indonesia melalui Dewan Standar Akuntansi Keuangan Ikatan Akuntansi Indonesia (DSAK IAI) telah mengadopsi IAS 11 ke dalam Pernyataan Standar Akuntansi Keuangan (PSAK) nomor 34 yang disahkan tanggal 27 Agustus 2014.

Dalam perkembangannya, International Accounting Standard Boards (IASB) selaku lembaga yang menerbitkan International Financial Reporting Standard (IFRS), bekerja sama dengan Financial Accounting Standard Boards (FASB) melakukan amandemen terhadap IAS 11 "Construction Contracts", IAS 18 "Revenue", IFRIC 13 "Customer Loyalty Programmes", IFRIC 15 "Agreement for the Construction of Real Estate", IFRIC 18 "Transfer of Assets from Customers" serta SIC 31 "Revenue - Barter Transactions" dengan mengeluarkan paket peraturan baru yang dituangkan dalam IFRS 15 (Simbolon dan Setiawan, 2016). IFRS 15 "Revenue From Contracts With Customers" adalah sebuah jawaban dari tuntutan dunia akuntansi untuk mengurangi gap atau perbedaaan terkait metode pengakuan pendapatan antara IFRS dan United States Generally Accepted Accounting Principles (US GAAP) yang ada sebelumnya.

Pada awalnya IFRS 15 akan diterapkan mulai tanggal 1 Januari 2017, namun dalam perkembangannya, sejak tanggal 28 April 2015 IASB telah memutuskan untuk menerbitkan exposure draft dengan tujuan untuk menunda tanggal efektif IFRS 15 menjadi 1 Januari 2018 di seluruh dunia. Indonesia melalui DSAK IAI telah mengesahkan PSAK 72 "Pendapatan dari Kontrak dengan Pelanggan" sebagai adopsi dari IFRS 15 . PSAK 72 diberlakukan secara efektif mulai tanggal 1 Januari 2020 dengan opsi penerapan dini, artinya setiap perusahaan dibolehkan jika ingin mengimplementasikan PSAK 72 sebelum tanggal efektif (IAIGLOBAL, 2017). Menurut Purba (2018), selain menggantikan PSAK 34, PSAK 72 juga menggantikan PSAK 23 tentang "Pendapatan"; Interpretasi Standar Akuntansi Keuangan (ISAK) nomor 10 tentang "Program Loyalitas Pelanggan", ISAK 21 tentang "Perjanjian Konstruksi Real Estate"; ISAK 27 tentang "Pengalihan Aset dari pelanggan”; PSAK 44 tentang "Akuntansi Aktivitas Pengembangan Real Estate"; dan Bagan Akun Standar "Perlakuan Akuntansi dan Keterbukaan dalam Transaksi Hubungan Keagenan".

Perubahan prinsip pengakuan pendapatan pada kontrak dengan pelanggan yang dibawa oleh IFRS 15 tentu saja akan membawa dampak kepada entitas perusahaan yang mengadopsinya. Menurut Wahyuni (2017) pengakuan pendapatan dalam masa pembangunan harus memenuhi persyaratan yang semakin ketat sehingga akan menimbulkan dampak yang nyata terhadap Industri real estate. Industri lainnya yang akan terkena akibat dari pengakuan pendapatan terhadap produk gabungan adalah industri telekomunikasi. Sedangkan menurut Sinaga (2019) IFRS 15 diterapkan dalam seluruh jenis industri. 
Penerapan IFRS 15 menimbulkan pengaruh yang sangat signifikan pada industri telekomunikasi, kontrak konstruksi, ritel dan pengembang. Tong (2014) juga mengatakan bahwa perusahaan atau industri dengan kontrak kompleks seperti kontrak jangka panjang atau multi-elemen arrangement, standar baru ini dapat mengakibatkan pengaruh besar pada jumlah dan/atau waktu pengakuan pendapatan, industri tersebut seringkali terkait dengan konstruksi, pembuatan dan industri perangkat lunak khusus. Artinya, perusahaan perusahaan yang sebagian besar pendapatannya diperoleh dari kontrak konstruksi jangka panjang akan mengalami dampak yang signifikan atas diberlakukannya standar baru ini. Industri konstruksi, real estate, dan telekomunikasi di Indonesia juga mengalami kekhawatiran serupa dikarenakan suatu perusahaan harus memenuhi persyaratan yang lebih ketat untuk mengakui pendapatan sepanjang masa pembangunan berlangsung.

IFRS 15 sudah diterapkan di negara - negara lain, salah satunya adalah Perancis, yaitu sejak 1 Januari 2018. Penelitian ini dimaksudkan untuk mengetahui analisis dampak penggunaan / implementasi IFRS 15 terhadap salah satu perusahaan konstruksi terbesar di Perancis yaitu Bouygues S.A. Dipilih Bouygues S.A. dikarenakan selain termasuk dalam "The World Largest Company" versi majalah Forbes Global 2000 tahun 2019, perusahaan ini diketahui bergerak di berbagai sektor bisnis, dengan bisnis utama adalah jasa konstruksi, telekomunikasi serta real estate (Bouygues, 2018). Sektor bisnis tersebut sebagian besar pendapatannya diperoleh melalui kontrak jangka panjang dengan pelanggan, sehingga sangat mungkin mengalami dampak terhadap penerapan IFRS 15 sebagaimana dipaparkan sebelumnya. Perancis dipilih karena perusahaan-perusahaan di negara ini memungkinkan pembaca untuk secara detail mengetahui dampak yang ditimbulkan atas penerapan IFRS 15 hingga ke setiap akun dalam Laporan Keuangan. Penelitian ini tidak dilakukan di Indonesia karena Indonesia sendiri baru akan menerapkan IFRS 15 melalui PSAK 72 mulai tanggal 1 Januari 2020.

Penelitian terdahulu mengenai dampak dari penggunaan IFRS 15 pada kualitas pendapatan dilakukan oleh Hameed dkk (2019). Penelitian tersebut menyimpulkan bahwa tidak terdapat dampak signifikan terhadap kualitas laba bersih terhadap kualitas pendapatan di dalam bisnis perhotelan (sektor real estate) di lingkungan negara Irak. Selanjutnya pada penelitian lainnya, Mattei dan Paoloni (2019) mengatakan terdapat korelasi langsung antara potensi dampak penerapan IFRS 15 dan kuantitas serta kualitas informasi yang disediakan dalam laporan tahunan yang diuraikan untuk dua tahun sebelum mengadopsi standar baru. Penelitian yang telah dilakukan oleh Trabelsi (2018) menyimpulkan bahwa penerapan IFRS 15 oleh perusahaan real estate di Dubai telah menghasilkan peningkatan dalam pengukuran indikator keuangan yaitu pendapatan dan ekuitas pemegang saham. Sedangkan kesimpulan yang diungkapkan Veronica dkk (2018) dalam penelitiannya adalah bahwa pengakuan pendapatan yang berdasar pada PSAK 72 (yang merupakan implementasi dari IFRS 15 di Indonesia) membuat kinerja keuangan perusahaan terlihat tidak baik jika dibandingkan 
dengan penggunaan standar sebelumnya. Selanjutnya Tutino dkk (2019) berpendapat bahwa penerapan prinsip baru yang dibuat untuk mendisiplinkan akuntansi pendapatan dan konsekuensinya harus dianalisis dan dipantau dengan cermat oleh regulator dan diadopsi dengan benar oleh manajer. Penelitian terbaru pada perusahaan di Indonesia oleh Aufa dkk (2019) menyatakan bahwa implementasi pengakuan pendapatan dari kontrak dengan pelanggan untuk single service pada sebuah perusahaan di Indonesia telah sesuai penerapannya berdasarkan IFRS 15.

Berbeda dari penelitian sebelumnya, penelitian ini bertujuan untuk mengetahui dampak dari implementasi IFRS 15 terkait pengakuan pendapatan kontrak dengan pelanggan pada sektor jasa konstruksi dan telekomunikasi termasuk juga real estate, melalui analisis Laporan Tahunan Bouygues S.A., sebuah perusahaan yang bermarkas pusat di Perancis. Penelitian ini akan menganalisis Laporan Keuangan Perusahaan Tahun 2017 (sebelum penggunaan IFRS 15) dan Laporan Keuangan Perusahaan Tahun 2017 (setelah penggunaan IFRS 15) dari perusahaan Bouygues S. A. Tahun 2017 dipilih, karena Bouygues S.A. mulai menerapkan IFRS 15 pada Laporan Keuangan mereka secara penuh di tahun 2018 dan telah melakukan penyesuaian dan penyusunan kembali terhadap Laporan Keuangan Tahun 2017, sehingga dimungkinkan untuk melakukan perbandingan terhadap penerapan IFRS 15 di tahun akuntansi yang sama dan menjadikan proses analisis menjadi lebih akurat.

Hasil dari penelitian ini diharapkan dapat memberikan gambaran dan informasi bagi perusahaan-perusahaan di Indonesia terkait dampak yang timbul apabila PSAK 72 diberlakukan di Indonesia sebagai adopsi atas IFRS 15. Selain itu penelitian ini diharapkan juga dapat menambah persiapan perusahan - perusahaan di Indonesia, terutama perusahaan yang bergerak di sektor jasa konstruksi, telekomunikasi dan real estate untuk mengambil langkah strategi bisnis terkait dengan penerapan PSAK 72.

\section{LANDASAN TEORITIS DAN PENGEMBANGAN HIPOTESIS Pengertian Pendapatan}

Menurut IAI (2009) yang dimaksud dengan pendapatan adalah arus masuk dari manfaat ekonomi akibat aktivitas perusahaan selama satu periode yang tidak berasal dari penanaman modal dan arus masuk tersebut menyebabkan kenaikan ekuitas pemilik modal. Pendapat dari Khairunnisa (2019) menyatakan bahwa pengambilan keputusan investasi oleh investor akan dipengaruhi oleh salah penyajian pada pos pendapatan di laporan keuangan. Oleh karena itu, aspek pengukuran, pengakuan dan penilaian pendapatan memerlukan perhatian yang lebih mendalam. Menurut Veronica dkk (2019) pendapatan merupakan salah satu akun penting dalam laporan keuangan yang nilainya sangat berguna bagi para pemakai laporan keuangan untuk mendapatkan informasi yang lengkap mengenai posisi keuangan dan menilai kinerja suatu perusahaan. Pendapatan juga digunakan sebagai poros penggerak perhitungan kinerja lain sebagai laba bersih dan laba per lembar saham. Pendapatan 
merupakan indikator untuk membentuk laba yang merupakan tujuan utama bagi perusahaan yang mengutamakan keuntungan (profit oriented), sehingga nilai pendapatan harus diukur secara wajar dan pada saat yang tepat sesuai prinsip pengakuan pendapatan yang berlaku.

\section{Pengertian Kontrak}

Menurut Subekti (1996) kontrak atau perjanjian dapat didefinisikan sebagai suatu kejadian dimana terdapat keterikatan atau janji diantara dua orang untuk melaksanakan suatu hal sehingga timbul sebuah "perikatan". Perikatan dari hubungan antara dua orang tersebut muncul akibat perjanjian yang telah dibuat. Sedangkan menurut PSAK 34, kontrak konstruksi adalah suatu kontrak yang dinegosiasikan khusus untuk konstruksi aset atau suatu kombinasi aset yang saling tergantung atau berhubung erat satu sama lain dalam hal tujuan pokok penggunaan, rancangan, fungsi dan teknologi.

\section{Prinsip Pengakuan Pendapatan}

IFRS 15 menyatakan bahwa pada prinsipnya pendapatan tidak boleh diakui sampai adanya suatu kontrak yang dapat berbentuk formal atau tertulis. Suatu kontrak akan menimbulkan hak dan kewajiban untuk menyerahkan barang dan jasa. Menurut Hameed dkk (2019) ada lima langkah yang harus ditempuh dalam IFRS 15 untuk mengakui sebuah pendapatan.

Pertama, mengidentifikasi kontrak dengan pelanggan, dimana kontrak dapat berbentuk lisan, tertulis, disesuaikan dengan praktik bisnis yang berlaku pada umumnya atau merepresentasikan sebuah perjanjian antara dua atau lebih pihak termasuk hak dan kewajiban yang dapat diberlakukan, dengan mempertimbangkan berbagai macam persyaratan. Syarat yang pertama bahwa pihak yang terikat dalam kontrak harus memiliki kemampuan untuk memenuhi kewajibannya dan meratifikasi kontrak tersebut. Selanjutnya hak-hak setiap pihak yang berkaitan dengan barang dan jasa yang akan ditransfer harus diukur dengan unit tertentu. Selanjutnya ketentuan pembayaran untuk barang dan jasa yang akan ditransfer dapat diukur dengan unit tertentu. Sebagai resikonya, waktu atau jumlah dari arus kas yang akan datang dari unit yang muncul di kontrak diperkirakan akan berubah. Kemudian kontrak harus bersifat komersial. Barang atau jasa yang belum diktransfer ke pelanggan dievaluasi kembali dikarenakan terdapat keraguan terkait niat pelanggan untuk membayar pada jatuh tempo dan kemampuan pelanggan untuk membayarnya

Kedua, mengidentifikasi performance obligation secara terpisah dalam kontrak. Pemisahan performance obligation dapat ditunjukkan di dalam kontrak dengan pelanggan. Janji yang diberikan dalam kontrak atas transfer barang atau jasa mungkin lebih jelas daripada performance obligation yang akan diberikan. Sebagai contoh, jika barang atau jasa yang dijanjikan akan ditransfer kepada pelanggan mengalami masalah dan gagal dikirim, maka unit yang harus bertanggungjawab atas berang atau jasa tersebut dianggap gagal memenuhi satu 
performance obligation, dan tidak berdampak pada unit lain karena telah dilakukan pemisahan. Contoh lainnya, ketika barang dan jasa yang dijanjikan akan ditransfer mengalami kegagalan pengiriman, sedangkan barang atau jasa tersebut terkait dan memiliki korelasi dengan barang atau jasa lainnya, maka atas sekelompok barang atau jasa tersebut dianggap memiliki satu performance obligation.

Ketiga, menentukan harga transaksi. Langkah ini memberikan penjelasan terkait jumlah dari kompensasi (biasanya uang) yang diharapkan untuk diterima dari pelanggan atas transfer barang atau jasa. Faktor - faktor yang mempengaruhi proses identifikasi adalah sifat, waktu dan jumlah kompensasi yang ditentukan ketika pelanggan setuju untuk membayar jumlah yang pasti kepada perusahaan atas kontrak spesifik tertentu.

Keempat, mengalokasikan harga transaksi . Perusahaan harus mengalokasikan harga transaksi terhadap lebih dari satu performance obligation di dalam kontrak berdasarkan nilai wajar relatifnya. Kemampuan perusahaan untuk menjual barang dan menyediakan jasa berdasarkan harga yang ditentukan sendiri adalah cara terbaik untuk menentukan nilai wajar. Perusahaan harus menggunakan berbagai instrumen atau input yang dapat diobservasi untuk memperoleh harga estimasi yang tepat jika mereka tidak dapat menentukan harga sendiri.

Kelima, mengakui pendapatan ketika performance obligation terpenuhi. Transfer kepemilikan atas barang dan jasa kepada pelanggan dilakukan ketika performance obligation terpenuhi. Setelah sebelumnya dialokasikan pada langkah ke-4 atas setiap performance obligation, jumlah final dari kompensasi yang dibayarkan oleh pelanggan akan sesuai dengan harga transaksi (langkah 3).

\section{Pengakuan Pendapatan Pada Kontrak Konstruksi Jangka Panjang}

Menurut Binder Dijker Otte [BDO] (2009) terkait pengakuan pendapatan pada kontrak konstruksi jangka panjang, IFRS 15 memberikan ketentuan - ketentuan penggunaan berbagai metode. Metode yang pertama digunakan adalah metode output. Metode ini melihat ukuran kemajuan asset yang ditransfer ke pelanggan. Metode output menggunakan pengukuran langsung atas barang atau jasa yang ditransfer kepada pelanggan. Metode ini menggunakan penilaian atas hasil yang dicapai atau unit yang diproduksi dan dikirim. Misalnya ketika dua lantai dari konstruksi sepuluh lantai telah dibangun, maka diakui sebanyak 2/10 dari pendapatan.

Metode selanjutnya adalah metode input. Metode ini melihat sumber daya yang telah digunakan saat asset ditransfer. Metode ini mengukur jumlah input yang digunakan entitas untuk memenuhi performance obligation, termasuk jam kerja yang dibutuhkan, sumber daya yang dikonsumsi, biaya yang dikeluarkan, jam mesin yang digunakan, atau waktu yang berlalu. Misalnya ketika 100.000 biaya telah dikeluarkan dari perkiraan total biaya proyek sebesar 1.000.000, maka diakui 1/10 dari pendapatan. 
IFRS 15 memberikan panduan yang lebih rinci tentang perlakuan "uninstalled materials" saat menerapkan metode pengukuran input (sebelumnya tidak diberikan dalam IAS 18 / IAS 11) sehingga dapat memengaruhi jumlah pendapatan yang diakui. Salah satu kekurangan dari metode input adalah dimungkinkan tidak terdapat hubungan langsung antara input dan barang atau jasa yang ditransfer kepada pelanggan, sehingga biaya yang dikeluarkan atas material yang terpakai tidak menggambarkan kemajuan perusahaan dalam memenuhi performance obligation.

Terkait metode output dan dampaknya kepada margin laba, menurut BDO (2009) di bawah IFRS 15, biaya untuk memenuhi performance obligation baik sepenuhnya atau sebagian harus dianggap sebagai beban ketika biaya tersebut muncul, sehingga dalam laporan laba rugi akan menghasilkan margin lebih banyak daripada di bawah standar akuntansi sebelumnya.

Sedangkan metode yang berlaku sebelumnya, yaitu Precentation of Completion (PoC) hanya berlaku jika pelanggan memiliki kontrol atas asset dan pengembangannya, tidak ada alternatif penggunaan atas asset tersebut dan entitas memiliki hak atas pembayaran untuk performance obligation yang diberikan (Tong, 2014). Selanjutnya untuk mengetahui bagaimana perubahan perubahan di atas membawa dampak kepada perusahaan, Simbolon dan Setiawan (2016) memberikan gambaran singkat terkait dampak yang akan terjadi bagi perusahaan yang mengadopsi standar baru ini.

Pertama, kompleksitas dalam melakukan identifikasi seluruh kontrak yang dimiliki oleh perusahaan. Effortyang besar dibutuhkan oleh perusahaaan atau bahkan mengubah business process jika harus mengidentifikasi kontrak dengan pelanggannya satu persatu. Apalagi selain kontrak tertulis, standar ini juga mengakomodasi kontrak secara lisan serta mengijinkan identifikasi kontrak secara grup atau protofolio sejauh terdapat persamaan barang dan jasa atau persamaan isi (term and condition).

Kedua, munculnya pengakuan contract liablities dan contract asset pada setiap performance obligation akibat dari perbedaan prinsip identifikasi. Contract liabilities muncul apabila right received lebih kecil dari performance obligation, jika terjadi sebaliknya maka akan muncul contract asset.

Ketiga, membutuhkan usaha lebih ketika melakukan penentuan harga dengan menggunakan time value of money, variable consideration, consideration paid or payable to customers dan non-cash consideration.

Keempat, kesulitan menentukan relative fair value atas setiap performance obligation.

Kelima, pada saat perpindahan pengendalian, entitas akan mengalami kesulitan pada saat mengidentifikasi pengakuan pendapatan. Hal ini terjadi secara khusus pada pengakuan pendapatan atas performance obligation dari waktu ke waktu (misal proyek konstruksi) Namun demikian, panduan perpindahan pengendalian sudah dijelaskan secara rinci pada IFRS 15. 


\section{METODE PENELITIAN}

Metode yang digunakan dalam penelitian kali ini menggunakan metode kualitatif dengan pendekatan studi literatur dan content analysis (analisis isi). Menurut Sugiyono (2017) metode penelitian kualitatif dilakukan untuk mengumpulkan data yang bersifat kualitatif dan menganalisis data tersebut pada kondisi yang alamiah (natural setting). Analisis terhadap data yang terkumpul pada penelitian ini juga lebih bersifat kualitatif. Penelitian ini menganalis data dan informasi yang bersumber dari Laporan Tahunan 2017 sebelum penerapan IFRS 15 dan Laporan Tahunan 2017 setelah penerapan IFRS 15 perusahaan Bouygues S.A.

\section{HASIL PENELITIAN DAN PEMBAHASAN}

Bouygues S.A merupakan perusahaan yang memiliki bisnis di bidang konstruksi, telekomunikasi dan real estate. Perusahaan ini bermarkas di Paris, Prancis. Menurut majalah Forbes Global 2000 (2019), perusahaan yang berdiri sejak tahun 1952 ini menempati posisi kedua sebagai perusahaan konstruksi terbesar di Prancis dan di Eropa serta berada di posisi ke 9 di dunia. Perusahaan ini telah menangani banyak proyek besar di berbagai belahan dunia. Diantaranya adalah monumen ikonik Parc de Princess di Prancis, Stadion Stade de France di Prancis, Iqaluit Airport di Amerika Utara, Hassan II Mosque di Afrika, Singapore Sport Hub di Singapura dan banyak lainnya. (Wikipedia,2019). Bouygues S.A. mulai melakukan implementasi IFRS 15 pada Laporan Keuangan mereka tahun 2018 dan melakukan penyesuaian terhadap Laporan Keuangan tahun 2017. Bouygues S.A. mengakui pendapatan konstruksi mereka dengan metode presentase penyelesaian. Berikut ini ringkasan Laporan Keuangan Bouygues S.A.

Table 1

Balance Sheet

2017

(in million euro)

\begin{tabular}{|l|r|r|r|r|r|r|r|}
\hline \multicolumn{1}{|c|}{ Assets } & $\begin{array}{c}31 / 12 / 2017 \\
\text { published }\end{array}$ & $\begin{array}{c}\text { Construction } \\
\text { businesses }\end{array}$ & $\begin{array}{c}\text { Bouygues } \\
\text { Telecom }\end{array}$ & $\begin{array}{c}\text { TF1 \& } \\
\text { other }\end{array}$ & $\begin{array}{c}\text { Total } \\
\text { impacts } \\
\text { of IFRS 15 }\end{array}$ & $\begin{array}{c}\text { Impacts } \\
\text { of IFRS 9 }\end{array}$ & $\begin{array}{c}31 / 12 / 2017 \\
\text { restated }\end{array}$ \\
\hline NON-CURRENT ASSETS & 17,777 & $(14)$ & $(199)$ & $(2)$ & $(215)$ & 6 & 17,568 \\
\hline CURRENT ASSETS & 17,963 & 146 & 609 & 2 & 757 & $(23)$ & 18,697 \\
\hline Held-for-sale assets and operations & 38 & & & & & & 38 \\
\hline TOTAL ASSETS & 35,778 & 132 & 410 & & 542 & $(17)$ & 36,303 \\
\hline
\end{tabular}

Secara umum penerapan IFRS 15 menambah total Asset sebesar 542 juta Euro, atau sekitar $1,514 \%$ dari jumlah total asset sebelumnya. Dari total tersebut, segmen bisnis telekomunikasi mengalami penambahan paling besar yaitu 410 juta Euro, dan segmen bisnis konstruksi mengalami penambahan asset sebesar 132 juta Euro.

Di bawah ini juga dirinci mengenai dampak IFRS terhadap liabilitas dan ekuitas, 
dengan total penambahan liabilitas sebesar 542 juta Euro atau 1,514\% dari total liabilitas sebelumnya. Sedangkan ekuitas mangalami penambahan sebesar 225 juta Euro atau 2,203 $\%$ dari total ekuitas sebelumnya.

Tabel 2 neraca

\begin{tabular}{|c|c|c|c|c|c|c|c|}
\hline $\begin{array}{c}\text { Liabilities and shareholders' } \\
\text { equity }\end{array}$ & $\begin{array}{l}31 / 12 / 2017 \\
\text { published }\end{array}$ & $\begin{array}{l}\text { Construction } \\
\text { businesses }\end{array}$ & $\begin{array}{l}\text { Bouygues } \\
\text { Telecom }\end{array}$ & $\begin{array}{l}\text { TF1 } \\
\& \\
\text { other }\end{array}$ & $\begin{array}{l}\text { Total } \\
\text { impacts } \\
\text { of IFRS } 15\end{array}$ & $\begin{array}{l}\text { Impacts } \\
\text { of IFRS } 9\end{array}$ & $\begin{array}{c}31 / 12 / 2017 \\
\text { restated }\end{array}$ \\
\hline $\begin{array}{l}\text { SHAREHOLDERS' } \\
\text { EQUTTY } \\
\text { ATTRIBUTABLE TO THE } \\
\text { GROUP }\end{array}$ & 8,851 & 65 & 145 & & 210 & (23) & 9,038 \\
\hline Non-controlling interests & 1,359 & & 15 & & 15 & 4 & 1,378 \\
\hline $\begin{array}{l}\text { SHAREHOLDERS' } \\
\text { EQUTTY }\end{array}$ & 10,210 & 65 & 160 & & 225 & (19) & 10,416 \\
\hline $\begin{array}{l}\text { NON-CURRENT } \\
\text { LIABILITIES }\end{array}$ & 8,020 & (7) & 113 & & 106 & 2 & 8,128 \\
\hline CURRENT LIABILITIES & 17,548 & 74 & 137 & & 211 & & 17,759 \\
\hline $\begin{array}{l}\text { Liabilities related to held- } \\
\text { for-sale operations }\end{array}$ & & & & & & & \\
\hline $\begin{array}{l}\text { TOTAL LIABILITIES } \\
\text { AND SHAREHOLDERS' } \\
\text { EQUTTY }\end{array}$ & 35,778 & 132 & 410 & & 542 & (17) & 36,303 \\
\hline $\begin{array}{l}\text { NET SURPLUS } \\
\text { CASH/NET DEBT) }\end{array}$ & $(1,914)$ & & & & & (3) & $(1,917)$ \\
\hline
\end{tabular}

Sumber: Annual Report Bouygues S.A, 2018 dan 2017 
Selanjutnya adalah dampak yang terjadi pada Laporan Laba Rugi Konsolidasi, yaitu sebagai berikut:

Tabel 3

Consolidated Income Statement

2017

\begin{tabular}{|c|c|c|c|c|c|c|}
\hline & $\begin{array}{l}\text { FY } 2017 \\
\text { Published }\end{array}$ & $\begin{array}{l}\text { Construction } \\
\text { businesses }\end{array}$ & $\begin{array}{l}\text { Bouygues } \\
\text { Telecom }\end{array}$ & $\begin{array}{l}\text { TF1 \& } \\
\text { other }\end{array}$ & $\begin{array}{c}\text { Total } \\
\text { impacts } \\
\text { of IFRS } \\
15\end{array}$ & $\begin{array}{l}\text { FY } 2017 \\
\text { restated }\end{array}$ \\
\hline SALES & 32,904 & 37 & (26) & 8 & 19 & 32,923 \\
\hline Other revenues from operations & 150 & & & & & 150 \\
\hline Purchases used in production & $(15,287)$ & (16) & & & (16) & $(15,303)$ \\
\hline Personnel costs & $(7,336)$ & & & & & $(7,336)$ \\
\hline External charges & $(7,280)$ & & (39) & (8) & (47) & $(7,327)$ \\
\hline Taxes other than income tax & $(668)$ & (1) & & 1 & & $(668)$ \\
\hline Net depreciation and amortisation expense & $(1,655)$ & & 59 & & 59 & $(1,596)$ \\
\hline $\begin{array}{l}\text { Charges to provisions and impairment losses, net of } \\
\text { reversals due to utilisation }\end{array}$ & $(330)$ & & & & & (330) \\
\hline $\begin{array}{l}\text { Change in production and property development } \\
\text { inventories }\end{array}$ & 85 & (25) & & & (25) & 60 \\
\hline Other income from operations & 1,672 & & (3) & (1) & (4) & 1,668 \\
\hline Other expenses on operations & $(835)$ & & & & & $(835)$ \\
\hline CURRENT OPERATING PROFIT/(LOSS) & 1,420 & $(5)$ & (9) & & (14) & 1,406 \\
\hline Other operating income & 233 & & & & & 233 \\
\hline Other operating expenses & $(120)$ & & & & & $(120)$ \\
\hline OPERATING PROFIT/(LOSS) & 1,533 & (5) & (9) & & (14) & 1,519 \\
\hline $\begin{array}{l}\text { INCOME FROM NET SURPLUS CASH/(COST } \\
\text { OF NET DEBT) }\end{array}$ & (226) & & & & & (226) \\
\hline Other financial income & 113 & & & & & 113 \\
\hline Other financial expenses & (75) & & & & & $(75)$ \\
\hline Income tax & (303) & & 4 & & 4 & (299) \\
\hline $\begin{array}{l}\text { Share of net profits/losses of joint ventures and } \\
\text { associates }\end{array}$ & 163 & 6 & & & 6 & 169 \\
\hline NET PROFIT/(LOSS) & 1,205 & 1 & (5) & & (4) & 1,201 \\
\hline
\end{tabular}

Sumber: Diolah dari Annual Report Bouygues S.A, 2018 dan 2017

Diketahui Sales Revenue mengalami penambahan sebesar 19 juta Euro atau 0,0577 \% dari jumlah awal. Sedangkan net profit mengalami penurunan sebesar 4 juta Euro atau $0,33319 \%$ dari jumlah awal. Presentase penambahan pendapatan dari penjualan yang diakui relatif sangat kecil, sedangkan penambahan total beban lebih besar sehingga secara total perusahaan mengalami penurunan laba bersih. Penambahan beban naik di akun Purchased used in Prodution sebesar 16 juta Euro atau 0,1046\% dari jumlah sebelumnya dan akun External charges sebesar 47 juta Euro atau 0,6456\%.

Berikut ini juga dirinci mengenai dampak penerapan IFRS 15 pada Statement Of Cash Flows. Arus kas dari aktivitas operasi berkurang sebesar 105 juta Euro atau 4,852\% dari total arus kas dari aktivitas operasi sebelumnya. Sedangkan dari aktivitas investasi arus kas bertambah sebesar 105 juta Euro atau sekitar 6,620\% dari total arus kas dari aktivitas investasi sebelumnya. Terakhir, dari aktivitas pendanaan, arus kas tidak mengalami perubahan atau 
tidak terkena dampak dari penerapan IFRS 15. Total dampak penerapan IFRS terhadap Free Cash Flow adalah 36 Juta Euro.

Table 4

Statement Of Cash Flow

2017

\begin{tabular}{|c|c|c|c|c|c|c|}
\hline & $\begin{array}{l}\text { FY } 2017 \\
\text { published }\end{array}$ & $\begin{array}{l}\text { Construction } \\
\text { businesses }\end{array}$ & $\begin{array}{l}\text { Bouygues } \\
\text { Telecom }\end{array}$ & $\begin{array}{l}\text { TF1 } \\
\& \text { other }\end{array}$ & $\begin{array}{l}\text { Total } \\
\text { impacts } \\
\text { of IFRS } \\
15\end{array}$ & $\begin{array}{l}\text { FY } \\
2017 \\
\text { restated }\end{array}$ \\
\hline \multicolumn{7}{|l|}{ CASH FLOW FROM CONTINUING OPERATIONS } \\
\hline \multicolumn{7}{|c|}{ A - NET CASH GENERATED BY/(USED IN) OPERATING ACTIVITIES } \\
\hline $\begin{array}{l}\text { NET CASH GENERATED BY/(USED IN) } \\
\text { OPERATING ACTIVITIES }\end{array}$ & 2,164 & & (104) & (1) & (105) & 2,059 \\
\hline \multicolumn{7}{|c|}{ B - NET CASH GENERATED BY/ (USED IN) INVESTING ACTIVIIIES } \\
\hline $\begin{array}{l}\text { NET CASH GENERATED BY/(USED IN) } \\
\text { INVESTING ACTIVITIES }\end{array}$ & $(1,586)$ & & 104 & 1 & 105 & $(1,481)$ \\
\hline \multicolumn{7}{|c|}{ C - NET CASH GENERATED BY/(USED IN)FINANCING ACTIVITIES } \\
\hline $\begin{array}{l}\text { NET CASH GENERATED BY/(USED } \\
\text { IN)FINANCING ACTIVITIES }\end{array}$ & (362) & & & & & (362) \\
\hline \multicolumn{7}{|l|}{ D - EFFECT OF FOREIGN EXCHANGE } \\
\hline \multicolumn{7}{|l|}{ CHANGE IN NET CASH POSITION } \\
\hline$(A+B+C+D)$ & 29 & & & & & 29 \\
\hline NET CASH POSITION AT START OF PERIOD & 45 & & & & & 4,581 \\
\hline Net cash flows & 29 & & & & & 29 \\
\hline Non-monetary flows & 1 & & & & & \\
\hline NET CASH POSITION AT END OF PERIOD & 4,611 & & & & & 4,611 \\
\hline FREE CASH FLOW & 828 & $(5)$ & 40 & 1 & 36 & 864 \\
\hline
\end{tabular}

Secara umum dampak penerapan IFRS 15 terhadap sistem akuntansi Bouygues S.A dijelaskan pada Notes 23 Annual Report 2019 Boyguese S.A Di bidang bisnis konstruksi, penerapan IFRS 15 berdampak pada perhitungan persentase penyelesaian proyek pengembangan properti residensial dan komersial. IFRS 15 yang berlaku saat ini akan mengakibatkan lebih banyak pendapatan dan keuntungan yang diakui di awal proyek dibandingkan praktik pada standar sebelumnya.

Di bidang telekomunikasi, terdapat pemisahan kontrak antara penjualan handset dan penyedia layanan jasa. Selain itu di pengakuan pendapatan, adanya percepatan pengakuan pendapatan pada penjualan handset yang mengakibatkan piutang dagang yang dilaporkan pada neraca berbeda antara harga yang dibayar oleh pelanggan pada pemasangan pertama dan harga transaksi. IFRS 15 juga mengubah perlakuan akuntansi terhadap distribusi kontrak dan tanggal pengakuan pendapatan yang dihasilkan oleh penjualan, namun secara umum tidak ada dampak material akibat perubahan tersebut.

Berdasarkan analisa terhadap laporan keuangan tahun 2017 (sebelum dan sesudah penggunaan IFRS 15) implementasi IFRS 15 terbukti tidak berdampak signifikan. Catatan atas Laporan Keuangan Bouyguese S.A menggambarkan proses bisnis yang berubah akibat diterapkannya IFRS 15, tetapi tidak terdapat catatan - catatan berupa kendala akibat 
penerapan IFRS 15, sehingga dapat disimpulkan bahwa penerapan IFRS 15 tidak berdampak signfikan terhadap proses bisnis dan sistem akuntansi Bouygues S.A

\section{KESIMPULAN DAN SARAN}

Bouygues S.A selaku perusahaan yang bergerak di bidang konstruksi dan telekomunikasi serta real estate, sudah menerapkan IFRS 15 terhadap Laporan Keuangan mereka pada tahun 2018. Sebagai perbandingan mereka juga melakukan penyesuaian atas Laporan Keuangan mereka pada tahun 2017 agar sesuai dengan IFRS 15. Secara umum penerapan IFRS 15 tidak berdampak signifikan terhadap kondisi keuangan Bouygues S.A. Perubahan Laporan Keuangan tahun 2017 yang disesuaikan, menunjukkan bahwa tidak ada akun yang mengalami perubahan kenaikan maupun penurunan lebih dari $5 \%$.

Penelitian ini dibatasi hanya pada analisis Laporan Keuangan, tidak ada studi lapangan maupun wawancara terhadap objek penelitian mungkin akan berdampak bahwa akun - akun yang dianalisa tidak menggambarkan kontrak jangka panjang secara keseluruhan. Data yang digunakan dalam penelitian ini adalah laporan keuangan tahun 2017 dan tahun 2018 Bouygues S.A. Fokus penelitian adalah menilai dampak implementasi IFRS 15 dari laporan keuangan Bouygues S.A

Perusahaan - perusahaan di Indonesia yang akan menerapkan PSAK 72 yang merupakan implementasi dari IFRS 15 di Indonesia per 1 Januari 2020 tidak perlu takut dengan kebijakan ini. Penelitian ini membuktikan bahwa penerapan IFRS 15 tidak berpengaruh secara signifikan di laporan keuangan. Namun perlu dipersiapkan untuk perubahan - perubahan perlakuan akuntansi yang mengubah proses bisnis sehingga perusahaan lebih siap dalam menyusun laporan keuangan.

Penelitian selanjutnya diharapkan dapat melakukan studi yang mendalam dengan metode observasi lapangan dan wawancara. Observasi lapangan diperlukan untuk menemukan kendala - kendala yang terjadi di proses bisnis di lapangan akibat dari implementasi IFRS 15. Metode wawancara digunakan untuk memperoleh dokumen dokumen keuangan yang tidak dibuka ke publik agar dapat dijadikan dasar penelitian sehingga hasil penelitian lebih optimal.

\section{DAFTAR PUSTAKA}

Binder Dijker Otte (2018). Article: IFRS 15 - how to measure revenue recognised over time. BDO UK. Diakses dari https://www.bdo.co.uk/en-gb/insights/business-edge/businessedge-2018/ifrs-15-how-to-measure-revenue-recognised-over-time

Bouygues S.A. (2019). 2018 Registration Dokumen. Paris: Bouygues S.A. Diakses dari https://www.bouygues.com/wp-content/uploads/2019/04/2018-registrationdocument.pdf

Forbes. (2019). The World's Largest Public Companies. Forbes. Diakses dari https://www.forbes.com/global2000/list/\#industry:Construction\%20Services_country:F rance 
Hameed, Anmar M., Al-taie, Bushra F. K., Al-Mashhadani, Bushra N. A., (2019). The Impact of IFRS 15 on Earnings Quality in businesses such as hotels: critical evidence from the Iraqi environment. African Journal of Hospitality, Tourism and Leisure. 8. 4. Diakses dari vol_8_4_2019_iraq.pdf https://www.ajhtl.com/uploads/7/1/6/3/7163688/article_58_

IFRS. (2017). IFRS 15 Revenue from Contracts with Customers. IFRS Foundation. Diakses dari https://www.ifrs.org/issued-standards/list-of-standards/ifrs-15-revenue-fromcontracts-with-customers/

Khairunnisa, A., Asliana, E., dan Dewi, Dian N. (2019). Implementasi Pengakuan Pendapatan Dari Kontrak Dengan Pelanggan Berdasarkan IFRS 15 Untuk Single Service Pada PT Aplikanusa Lintasarta. POLINELA. Diakses dari http://eprints.jeb.polinela.ac.id/402/

Litigasi. (2018). Kontrak Menurut Para Ahli. Litigasi News. Diakses dari https://litigasi.co.id/kontrak-menurut-ahli

Media Digital. (2019). Menakar Signifikansi Penerapan Standar Akuntansi Baru terhadap Korporasi Indonesia. Bisnis.com. Diakses dari https://finansial.bisnis.com/read/20190328/11/905482/menakar-signifikansi-

penerapan-standar-akuntansi-baru-terhadap-korporasi-indonesia

Mattei, G., Paoloni, N. (2019). Understanding the Potential Impact of IFRS 15 on the Telecommunication Listed Companies, by the Disclosures' Study. International Journal of Business and Management. 14. 169-179. Diakses dari https://www.researchgate.net/publication/329881006_Understanding_the_Potential_I mpact_of_IFRS_15_on_the_Telecommunication_Listed_Companies_by_the_Disclos ures'_Study

Pricewaterhouse Coopers. (2017). About IFRS 15. Pwc.com. Diakses dari https://www.pwc.com/vn/en/services/assurance/ifrs/ifrs-15.html

Purba, P. Marisi. (2018). Implikasi Pemberlakuan PSAK 72 Terhadap Pelaporan Keuangan. IAI Jawa Barat. Diakses dari https://iaijabar.or.id/wp-content/uploads/2018/12/Sesi-1PSAK-72.pdf

Selengke, Hasyim P., (2019, Mei 11)., Emiten Diminta Terapkan Standar Akuntansi Baru. Media Indonesia. Diakses dari https://mediaindonesia.com/read/detail/234965-emitendiminta-terapkan-standar-akuntansi-baru

Silvia. (2014). IFRS 15 vs. IAS 18: Huge Change Is Here!. IFRS box. Diakses dari https://www.ifrsbox.com/ifrs-15-vs-ias-18/

Simbolon, Harry A., dan Setiawan, Iwan. (2016, Juli). IFRS 15: Kekawatiran Yang Berlebihan?. Akuntansi Terapan. Diakses dari https://akuntansiterapan.com/2016/07/04/ifrs-15kekawatiran-yang-berlebihan/

Sugiyono. (2017). Metode Penelitian Kuantitatif, Kualitatif dan R\&D. Bandung: Afabeta, CV.

Tong, T. L. (2014). A Review of IFRS 15 Revenue from Contracts with Customers. In. Diakses dari 15\%20Review\%20of\%20IFRS\%2015\%20(TLT).pdf

Trabelsi, Sbei. N., (2018). IFRS 15 Early Adoption And Accounting Information: Case Of Real Estate Companies In Dubai. Academy of Accounting and Financial Studies Journal. 22. $1-12$ Diakses dari https://www.researchgate.net/publication/323666531_IFRS_15_early_adoption_and_ Accounting_Information_Case_of_Real_Estate_Companies_in_Dubai

Tutino, M., Regoliosi, C., Mattei, G., Paoloni, N., Pompili, M. (2019). Does the IFRS 15 impact earnings management? Initial evidence from Italian listed companies. African Journal of Business Management. 13. 226-238. Diakses dari https://www.researchgate.net/publication/332229545_Does_the_IFRS_15_impact_ea rnings_management_Initial_evidence_from_Italian_listed_companies

Wahyuni, Ersa T . (2017). Menghadapi Turbulensi IFRS 2018-2022. Diakses dari http://etwaccountant.com/tag/ifrs-15/

Veronica, Lestari, Utami P., Metekohy, dan Elisabeth, Y. (2018). Analisis Dampak Penerapan Pengakuan Pendapatan Berdasarkan PSAK 72 Terhadap Kinerja Keuangan Perusahaan Real Estat di Indonesia yang Terdaftar di Bursa Efek Indonesia Tahun 2018. IROWNS. Diakses dari https://jurnal.polban.ac.id/proceeding/ article/view/ 1451. 